\title{
Effect of Packaging Type and Aging on the Meat Quality Characteristics of Water Buffalo Bulls
}

\author{
Muhammad Hayat Jaspal ${ }^{1, *}$, Iftikhar Hussain Badar ${ }^{1,2, *(\mathbb{D})}$, Muhammad Usman Ghani ${ }^{1}$, Muawuz Ijaz ${ }^{3}$ (D), \\ Muhammad Kashif Yar ${ }^{3}{ }^{\mathbb{D}}$, Adeel Manzoor ${ }^{1}{ }^{\mathbb{D}}$, Jamal Nasir ${ }^{1} \mathbb{D}^{\mathbb{D}}$, Kashif Nauman $^{1} \mathbb{D}$, Muhammad Junaid Akhtar $^{1}$, \\ Abdur Rahman ${ }^{3}$ (D), Faisal Hussnain ${ }^{4}$ iD and Arfan Ahmad ${ }^{5}$
}

1 Department of Meat Science and Technology, Faculty of Animal Production and Technology, University of Veterinary and Animal Sciences, Lahore 54000, Pakistan; hamilton.usman@gmail.com (M.U.G.); adeel.rehman@uvas.edu.pk (A.M.); jamalnasir@uvas.edu.pk (J.N.); drkashif@uvas.edu.pk (K.N.); raojunaid452@gmail.com (M.J.A.)

2 College of Food Science, Northeast Agricultural University, Harbin 150030, China

3 Department of Animal Sciences, CVAS-Jhang 35200, University of Veterinary and Animal Sciences, Lahore 54000, Pakistan; muawuz.ijaz@uvas.edu.pk (M.I.); Kashif.yar@uvas.edu.pk (M.K.Y.); abdurrehman@uvas.edu.pk (A.R.)

4 Department of Poultry Production, Faculty of Animal Production and Technology, University of Veterinary and Animal Sciences, Lahore 54000, Pakistan; faisal.hussnain@uvas.edu.pk

5 Institute of Microbiology, University of Veterinary and Animal Sciences, Lahore 54000, Pakistan; iffivet@uvas.edu.pk

* Correspondence: hayat.jaspal@uvas.edu.pk (M.H.J.); iftikhar.hussain@uvas.edu.pk (I.H.B.); Tel.: +92-333-1402020 (M.H.J.); +86-18645055905 (I.H.B.)

check for updates

Citation: Jaspal, M.H.; Badar, I.H.; Usman Ghani, M.; Ijaz, M.; Yar, M.K.; Manzoor, A.; Nasir, J.; Nauman, K.; Junaid Akhtar, M.; Rahman, A.; et al. Effect of Packaging Type and Aging on the Meat Quality Characteristics of Water Buffalo Bulls. Animals 2022, 12, 130. https://doi.org/10.3390/ ani12020130

Academic Editor: Hideaki Takahashi

Received: 20 September 2021

Accepted: 4 January 2022

Published: 6 January 2022

Publisher's Note: MDPI stays neutral with regard to jurisdictional claims in published maps and institutional affiliations.

Copyright: (c) 2022 by the authors. Licensee MDPI, Basel, Switzerland. This article is an open access article distributed under the terms and conditions of the Creative Commons Attribution (CC BY) license (https:// creativecommons.org/licenses/by/ $4.0 /)$.
Simple Summary: The water buffalo is found worldwide, but mainly in Asian countries, i.e., India, Pakistan, and China. Buffalo meat can be a viable option to fulfill the future protein demands of the world's population. Presently, very little information is available regarding buffalo meat quality attributes under different packaging types. Therefore, this study was designed to evaluate the effect of packaging type and aging time on the meat quality characteristics (instrumental color, WBSF, cooking loss, thiobarbituric acid reactive substances (TBARS), and total volatile basic nitrogen (TVB-N) of longissimus lumborum steaks. The results showed that vacuum packaging and aging were the most effective in decreasing the WBSF values of buffalo meat.

Abstract: The present study determined the effect of the packaging type and aging time on the meat quality of water buffalo (Bubalus bubalis) bulls. A total of $n=36$ longissimus lumborum (LL) muscles from $n=18$ buffalo bulls were obtained. Half LL muscles were packed in modified atmosphere packaging $\left(\mathrm{Hi}-\mathrm{O}_{2} \mathrm{MAP}\right)$, vacuum packaging $(\mathrm{VP})$, and oxygen-permeable packaging $(\mathrm{OP})$ on day 1 , while the other half were aged for 7 days. Meat instrumental color, cooking loss, Warner-Bratzler shear force (WBSF), thiobarbituric acid reactive substances (TBARS), and total volatile basic nitrogen (TVB-N) of the LL steaks were analyzed, both on unaged and aged buffalo meat. Color CIE L* and $\mathrm{C}^{*}$ values on all display days and $\mathrm{a}^{*}$ on the first 4 days of the simulated retail display under $\mathrm{Hi}-\mathrm{O}_{2}$ MAP packaging were significantly higher than those of the VP and OP. WBSF and TBARS values were also higher under $\mathrm{Hi}-\mathrm{O}_{2} \mathrm{MAP}$ as compared to the other packaging. Steaks under OP exhibited lower cooking loss but higher TVB-N values than the MAP and VP. The 7-day-aged buffalo meat indicated higher instrumental color $\left(\mathrm{L}^{*}, \mathrm{a}^{*}\right.$ and $\left.\mathrm{C}^{*}\right)$, cooking loss, and lower WBSF values than fresh meat. This study concluded that $\mathrm{Hi}-\mathrm{O}_{2} \mathrm{MAP}$ improved the color; however, it negatively influenced the buffalo meat's WBSF and TBAR values. Furthermore, VP and aging were the most effective in decreasing the WBSF values of buffalo meat.

Keywords: buffalo beef; meat packaging technologies; meat quality characteristics; meat-eating quality 


\section{Introduction}

Retail packaging has prime importance in the meat industry, as it serves many purposes, including product identification, promotion, and protection [1]. Meat packaging is also used to delay microbial spoilage, reduce weight loss, maintain the color and permit some intrinsic enzymes to improve the tenderness [2-4]. Traditionally, different types of retail packaging such as oxygen-permeable $(\mathrm{OP})$ packaging, high oxygen modified atmosphere packaging $\left(\mathrm{Hi}-\mathrm{O}_{2} \mathrm{MAP}\right)$, and vacuum packaging (VP) are used in the meat industry. $\mathrm{Hi}_{2} \mathrm{O}$ MAP $\left(80 \% \mathrm{O}_{2}: 20 \% \mathrm{CO}_{2}\right)$ is commonly used for retail display as it enhances the red color and prolongs the shelf-life of meat, compared to OP packaging [5]. High oxygen in the MAP maintains the myoglobin in oxygenated form [6], while carbon dioxide retards the growth of aerobic bacteria [7]. However, $\mathrm{Hi}-\mathrm{O}_{2}-\mathrm{MAP}$ has been linked with reduced tenderness and negative flavor due to protein and lipid oxidation [8,9]. At the same time, VP has been famous for improving meat tenderness and extending shelf life [10]. Since removing air eliminates the oxidizing effect in VP, it allows longer aging times to delay lipid oxidation and meat discoloration [11-14]. Other considerable advantages of VP are that it requires less space, is easy to handle, and provides a longer shelf-life [15].

Beef aging is a technique widely used in the meat industry to enhance tenderness and produce a uniform product that is highly acceptable to the consumers, and therefore, extensive work has been done in this area [4,16-20]. Almost eight out of ten consumer decisions to repurchase meat are based on the tenderness of the meat, and for that reason, its better understanding is a significant challenge, mainly when the rate of aging varies among different species and different types of muscles [21]. According to McKenna et al. [22], color during retail display is the consumers' main quality criteria and is associated with freshness and wholesomeness when purchasing meat and meat products. Alongside improving meat tenderness, aging also improves the color characteristics of the meat [23].

Different packaging types have been widely used to improve the retail shelf life of cattle meat [23-28]. However, the effect of the packaging type on the quality characteristics of buffalo meat has not been extensively studied. The water buffalo (Bubalus bubalis) inhabits many countries worldwide; $97.2 \%$ of the total buffalo population is found in Asia [29], particularly in India, Pakistan, and China, while $1.9 \%$ in Africa and the rest is present in Europe and Latin America [30,31]. Therefore, the principal objective of this study was to investigate the effect of $\mathrm{Hi}-\mathrm{O}_{2} \mathrm{MAP}, \mathrm{VP}$, and OP packaging on color, tenderness, and cooking loss of fresh and aged meat of young buffalo bulls.

\section{Materials and Methods}

\subsection{Animal Rearing}

Buffalo bulls ( $n=18$, Nili-Ravi breed) were reared at a commercial fattening farm Big Feed (Pvt.) Ltd., Lahore, Pakistan. Animals were raised under a similar feeding strategy (feed-lot fattening) and had the same pre-slaughter management conditions throughout the rearing period. At 24 months of age (average live weight $290 \pm 10 \mathrm{~kg}$ ), the animals were transported to the lairage facility of the University of Veterinary and Animal Sciences, Lahore, Pakistan.

\subsection{Animal Slaughtering}

Before slaughter, all animals were kept off-feed for $12 \mathrm{~h}$ with free access to water for the hygienic dressing of the carcasses. All animals were slaughtered by the Halal Slaughtering method described in Pakistan Halal Standards, PS 3733:2013 at the commercial slaughterhouse of Department of Meat Science and Technology, University of Veterinary and Animal Sciences, Lahore, Pakistan. After evisceration, carcasses were divided into two equal sagittal halves, hung from the Achilles tendon, and shifted to the walk-in chiller. The carcasses were chilled at $0-2{ }^{\circ} \mathrm{C}$ for $24 \mathrm{~h}$. 


\subsection{Muscle Sampling and Packaging}

After chilling, longissimus lumborum (LL) muscles from the 13th thoracic vertebrae to the lumbosacral junction were excised from both sides of each carcass. The left-side LL was vacuum packed using a C300 twin-chamber vacuum packing machine (Multivac Ltd., Wolfertschwenden, Germany) and placed in a dark room at $0-1{ }^{\circ} \mathrm{C}$ for 7 days aging period. The right-sided LL was cut into 9 steaks, each having a thickness of $2.5 \mathrm{~cm}$ [4]. A similar procedure was adopted for the left-sided LL after 7 days of aging. A brief layout of the experimental design is shown in Table 1 . Three steaks were randomly assigned the following packaging:

1. High oxygen $\left(\mathrm{Hi}-\mathrm{O}_{2}\right)$ MAP $\left(80 \% \mathrm{O}_{2}: 20 \% \mathrm{CO}_{2}\right)$ using T200 MAP machine (Multivac Ltd., Swindon, UK)

2. Vacuum packaging (VP) using C300 twin-chamber vacuum packing machine (Multivac Ltd., Wolfertschwenden, Germany)

3. Overwrapped with oxygen permeable (OP) film in food-grade polystyrene trays

Table 1. A brief layout of experimental design.

\begin{tabular}{|c|c|c|c|}
\hline Total Animals & Muscle & Ageing Time & Packaging \\
\hline $\begin{array}{c}\text { Buffalo bulls } \\
n=18\end{array}$ & \multirow{2}{*}{$\begin{array}{l}\text { Both sided longissimus lumborum } \\
\text { (LL) muscles were removed }\end{array}$} & $\begin{array}{l}0 \text { day } \\
\text { Right sided LL is divided into } \\
\text { steaks }(n=9) \text { of } 2.5 \mathrm{~cm} \text { thickness }\end{array}$ & $\begin{array}{l}\text { MAP (3 steaks) } \\
\text { Vacuum packed (3 steaks) } \\
\text { Overwrapped (3 steaks) }\end{array}$ \\
\hline $\begin{array}{c}24 \text { months } \\
\text { Carcass weight }(130 \pm 10 \mathrm{~kg})\end{array}$ & & $\begin{array}{c}7 \text { day } \\
\text { Left sided LL is divided into } \\
\text { steaks }(n=9) \text { of } 2.5 \mathrm{~cm} \text { thickness } \\
\text { after } 7 \text { days of aging }\end{array}$ & $\begin{array}{l}\text { MAP (3 steaks) } \\
\text { Vacuum packed (3 steaks) } \\
\text { Overwrapped (3 steaks) }\end{array}$ \\
\hline
\end{tabular}

All packaged steaks underwent simulated display in a horizontal display chiller (Model: S80100VVC, Tecnodom SPA, Vigodarzere, Italy), working at $0-4{ }^{\circ} \mathrm{C}$ for 7 days to check the color stability. The light source was provided by fluorescent tubes (TLD 36 W/33-640, Philips, Karachi, Pakistan) with 500 lux light intensity recorded with a digital lux meter (AR823, Bestone Industrial Ltd., Shenzhen, China) for $12 \mathrm{~h}$ each day. The same procedure was adopted for 7-day-aged samples. The MAP film (PET-PVDC-PE) with a permeability of $5 \mathrm{~cm}^{3} / 24 \mathrm{~h} / \mathrm{m}^{2} /$ atm oxygen, $20 \mathrm{~cm}^{3} / 24 \mathrm{~h} / \mathrm{m}^{2} /$ atm carbon dioxide, and $4 \mathrm{~g} / 24 \mathrm{~h} / \mathrm{m}^{2}$ of water vapor was used, while plastic trays were made of polypropylene. Vacuum bags were made of polyethylene (PA/PE 90) with absorbency: $2.6 \mathrm{~g} / \mathrm{m}^{2} . \mathrm{d}$ of water vapor, $50 \mathrm{~cm}^{3} / \mathrm{m}^{2}$ of oxygen, $150 \mathrm{~cm}^{3} / \mathrm{m}^{2}$ of carbon dioxide, $10 \mathrm{~cm}^{3} / \mathrm{m}^{2}$ of nitrogen.

\subsection{Meat Quality Analysis}

\subsubsection{Instrumental Color}

Samples packed in MAP, VP and OP were evaluated for color parameters for seven consecutive days. Color parameters: lightness $\left(\mathrm{L}^{*}\right)$, redness $\left(\mathrm{a}^{*}\right)$, and chroma $\left(\mathrm{C}^{*}\right)$ of the steaks were measured at three different sites of each steak using chroma meter (Konica Minolta CR-410, Tokyo, Japan). Then these values were averaged for statistical analysis. Minolta Chroma meter was calibrated each time using standard white tile $\left(\mathrm{L}^{*}=94.93, \mathrm{a}^{*}=-0.13\right.$, and $\left.\mathrm{C}^{*}=2.55\right)$, CR-A44 No.15533024 provided by the manufacturer. The colorimeter used D-65 illuminant, $50 \mathrm{~mm}$ aperture, and $2^{\circ}$ observer.

\subsubsection{Cooking Loss}

After 7 days of simulated retail display, steaks were weighed and vacuum packed in polyethylene bags $(150 \times 200$, PA/PE 90), using C300 twin-chamber vacuum packing machine (Multivac Ltd., Wolfertschwenden, Germany). The samples were cooked in a water bath (WNB45, Memmert GmbH + Co. KG, Schwabach, Germany) operating at $82{ }^{\circ} \mathrm{C}$ [32]. The core temperature of steaks was recorded by a digital thermometer (TP300, E-Maker Technology Co., Ltd., Shenzhen, China). After attaining the core temperature of $72{ }^{\circ} \mathrm{C}$, steaks were removed from the water bath and weighed again. The weight of 
steaks before and after cooking was recorded using a digital weighing balance (SF-400, Zhejiang Tiansheng Electronic Ltd., Zhejiang, China). The cooking loss was measured as a percentage, as the ratio of the difference between the weights before and after cooking to the weight of steaks before cooking [33].

\subsubsection{Warner-Bratzler Shear Force}

After cooking, steaks were placed in polystyrene trays and cooled down overnight at $0-2{ }^{\circ} \mathrm{C}$ [34]. The next day, $1 \mathrm{~cm}^{3}$ cross-section meat strips were obtained using scalpelhandle blades with a fiber direction parallel to the strip length [35]. Warner-Bratzler shear force values were measured in newton per centimeter square $\left(\mathrm{N} / \mathrm{cm}^{2}\right)$ by TA.XTplus texture analyzer (Stable Micro System Ltd., Godalming, UK) using a 'V-Slot' blade. Minimum of three shear force values were recorded for each sample and averaged for statistical analysis.

\subsubsection{Lipid Oxidation}

Lipid oxidation was determined through thiobarbituric acid reactive substances (TBARS) values following the method described by Zhang et al. [36] with some modifications. After 7 days of simulated retail display, $5 \mathrm{~g}$ of the meat samples were taken from three different sites of each steak's surface. The sample was transferred to a 50 milliliter (mL) conical tube, and $1 \mathrm{~mL}$ of $10 \%$ BHA (Butylated hydroxyanisole) solution (prepared in ethanol) was added along with $14 \mathrm{~mL}$ double-distilled water and homogenized using a T 25 digital Ultra-Turrax homogenizer (IKA-Werke GmbH \& Co., Staufen, Germany) at $11,000 \mathrm{rpm}$ for $15 \mathrm{~s}$. After that, homogenate $(1 \mathrm{~mL})$ was added to a test tube along with a $2 \mathrm{~mL}$ solution of TBA/TCA (thiobarbituric acid/trichloroacetic acid), vortexed for mixing, filtered, and was incubated in a water bath operating at $80^{\circ} \mathrm{C}$ for $90 \mathrm{~min}$; then, the sample was allowed to cool down, vortexed again, and centrifuged for $15 \mathrm{~min}$ at $2000 \mathrm{rpm}$. The absorbance of the supernatant was measured at $532 \mathrm{~nm}$ in a spectrophotometer (Shimadzu UV-1800 spectrophotometer, Kyoto, Japan). The TBARS values were expressed as mg of malonaldehyde (MDA) per $\mathrm{kg}$ of meat samples.

\subsubsection{Total Volatile Basic Nitrogen (TVB-N)}

The TVB-N content was calculated as described by Chen et al. [37] with some modifications. The $10 \mathrm{~g}$ representative sample was collected from three different sites of each steak's surface. The samples were homogenized in $100 \mathrm{~mL}$ distilled water at 11,000 rpm using a T 25 digital Ultra-Turrax homogenizer (IKA-Werke GmbH \& Co., Staufen, Germany). Then the homogenate was shifted to the distillation tube and $1 \mathrm{~g}$ magnesium oxide $(\mathrm{MgO})$ was added. The distillation tube was connected to the Kjeldhal Apparatus K 355 (BÜCHI Labortechnik AG, Flawil, Switzerland). The volatile basic nitrogen was absorbed using a $20 \mathrm{~mL}$ boric acid solution ( $2 \%$ ) containing color indicators (i.e., $0.1 \mathrm{~g}$ methylene blue and $0.1 \mathrm{~g}$ methyl red). After, the titration was performed using $0.01 \mathrm{~N}$ hydrochloric acid $(\mathrm{HCl})$ solution. The TVB-N values were expressed in $\mathrm{mg} / 100 \mathrm{~g}$ and calculated as follows:

TVB-N $=($ Vol. of HCL used $\times$ Normality of acid $\times 14) /$ Sample weight $(\mathrm{g}) \times 100$

\subsection{Statistical Analysis}

Statistical analysis was performed by SAS software (Version 9.1.3; 2002-2004, Cary, NC, USA). Effects of $\mathrm{Hi}_{-} \mathrm{O}_{2} \mathrm{MAP}, \mathrm{VP}, \mathrm{OP}$, and aging time on meat quality characteristics were analyzed through factorial ANOVA, using PROC GLM (general linear model), including packaging type and aging time as a fixed effect, and their interaction was also tested. There were non-significant interactions between packaging type and aging time. Therefore, interactions effects are not shown in the tables. Significant treatment means were compared using the Duncan multiple range DMR test [38]. The significance level was considered at $p \leq 0.05$.

Following statistical model was used:

$$
Y=\mu+F 1 i+F 2 j+(F 1 F 2) i j+\varepsilon i j
$$


where $\mathrm{Y}=$ response variable, $\mu$ = overall population mean, $\mathrm{F} 1 \mathrm{i}=$ fixed effect of packaging type, $\mathrm{F} 2 \mathrm{j}$ = fixed effect of aging time, $(\mathrm{F} 1 \mathrm{~F} 2) \mathrm{ij}$ = interaction effect of packaging type and aging time, and $\varepsilon \mathrm{ij}=$ random error.

\section{Results and Discussion}

\subsection{Instrumental Meat Color}

The influence of packaging type on instrumental color is presented in Table 2. Packaging type significantly affected $\mathrm{L}^{*}, \mathrm{a}^{*}$, and $\mathrm{C}^{*}$ values throughout the 7 days of simulated retail display. The $\mathrm{L}^{*}$ value of buffalo meat packed in $\mathrm{Hi}-\mathrm{O}_{2}$ MAP was highest $(p \leq 0.05)$, followed by OP and VP, respectively. A decreasing trend of $L^{*}$ value was found in all three packaging types throughout the 7 days of simulated retail display. The $a^{*}$ value of the buffalo LL steaks packed in $\mathrm{Hi}-\mathrm{O}_{2}$ MAP was highest $(p \leq 0.05)$ up to day 6 , whereas the $a^{*}$ value of OP packed buffalo meat was higher than VP on days 1 and 2 . It was similar to the $a^{*}$ value of VP buffalo meat on day 3, while it was lower on days 4, 5, 6, and 7 than VP meat. The $\mathrm{a}^{*}$ value was reduced throughout the 7 days of retail display in all three types of packaging. The $\mathrm{C}^{*}$ value of buffalo meat packed in $\mathrm{Hi}-\mathrm{O}_{2} \mathrm{MAP}$ was significantly higher than OP and VP meat throughout the 7 days of retail display. OP exhibited a higher $C^{*}$ value than VP from day 1 to day 4, while on day 5 and day 6 , VP indicated significantly higher $C^{*}$ values than OP buffalo meat. The $C^{*}$ value decreased with time in all three types of packaging.

Table 2. Effect of packaging and ageing on color $\mathrm{CIE} \mathrm{L}^{*}, \mathrm{a}^{*}$ and $\mathrm{C}^{*}$ of buffalo bulls longissimus lumborum steaks during the 7 days of retail display.

\begin{tabular}{|c|c|c|c|c|c|c|c|c|}
\hline \multirow{2}{*}{ Parameters } & \multirow{2}{*}{ Day } & \multicolumn{3}{|c|}{ Packaging } & \multirow{2}{*}{$p$-Value } & \multicolumn{2}{|c|}{ Ageing } & \multirow{2}{*}{$p$-Value } \\
\hline & & MAP & VP & OP & & 0 day & 7 day & \\
\hline \multirow{7}{*}{ Lightness L* } & 1 & $49.37 \pm 0.23^{a}$ & $42.22 \pm 0.18^{c}$ & $46.69 \pm 0.15^{b}$ & * & $45.89 \pm 0.44$ & $46.29 \pm 0.43$ & ns \\
\hline & 2 & $50.01 \pm 0.21^{\mathrm{a}}$ & $42.32 \pm 0.16^{c}$ & $46.51 \pm 0.12^{b}$ & * & $46.18 \pm 0.44$ & $46.39 \pm 0.46$ & ns \\
\hline & 3 & $49.98 \pm 0.19^{a}$ & $42.31 \pm 0.16^{\mathrm{c}}$ & $46.32 \pm 0.18^{b}$ & * & $46.00 \pm 0.43^{b}$ & $46.41 \pm 0.47^{\mathrm{a}}$ & * \\
\hline & 4 & $49.86 \pm 0.20^{\mathrm{a}}$ & $42.17 \pm 0.21^{c}$ & $45.73 \pm 0.25^{b}$ & $*$ & $45.77 \pm 0.44$ & $46.07 \pm 0.50$ & ns \\
\hline & 5 & $49.74 \pm 0.23^{\mathrm{a}}$ & $42.13 \pm 0.23^{c}$ & $45.58 \pm 0.22^{b}$ & * & $45.51 \pm 0.46^{b}$ & $46.12 \pm 0.47^{\mathrm{a}}$ & $*$ \\
\hline & 6 & $48.70 \pm 0.23^{a}$ & $42.19 \pm 0.22^{\mathrm{c}}$ & $44.98 \pm 0.17^{\mathrm{b}}$ & * & $45.38 \pm 0.42$ & $45.21 \pm 0.39$ & ns \\
\hline & 7 & $48.71 \pm 0.21^{\mathrm{a}}$ & $41.84 \pm 0.23^{c}$ & $44.85 \pm 0.16^{b}$ & * & $45.21 \pm 0.43$ & $45.06 \pm 0.41$ & ns \\
\hline \multirow{7}{*}{ Redness $a^{*}$} & 1 & $17.98 \pm 0.20^{\mathrm{a}}$ & $15.48 \pm 0.13^{c}$ & $17.41 \pm 0.18^{\mathrm{b}}$ & * & $16.52 \pm 0.15^{b}$ & $17.39 \pm 0.23^{a}$ & * \\
\hline & 2 & $17.22 \pm 0.15^{\mathrm{a}}$ & $15.20 \pm 0.10^{c}$ & $16.40 \pm 0.19^{b}$ & * & $16.15 \pm 0.15$ & $16.40 \pm 0.18$ & ns \\
\hline & 3 & $16.55 \pm 0.22^{\mathrm{a}}$ & $15.23 \pm 0.12^{b}$ & $15.22 \pm 0.15^{b}$ & * & $15.53 \pm 0.13$ & $15.80 \pm 0.14$ & ns \\
\hline & 4 & $15.72 \pm 0.13^{\mathrm{a}}$ & $15.01 \pm 0.09^{b}$ & $14.40 \pm 0.15^{c}$ & * & $14.98 \pm 0.12$ & $15.11 \pm 0.13$ & ns \\
\hline & 5 & $14.98 \pm 0.15^{\mathrm{a}}$ & $14.89 \pm 0.12^{\mathrm{a}}$ & $13.45 \pm 0.17^{b}$ & * & $14.48 \pm 0.15$ & $14.40 \pm 0.16$ & ns \\
\hline & 6 & $14.37 \pm 0.21^{\mathrm{a}}$ & $14.80 \pm 0.15^{\mathrm{a}}$ & $12.45 \pm 0.20^{b}$ & * & $13.95 \pm 0.19$ & $13.80 \pm 0.22$ & ns \\
\hline & 7 & $13.49 \pm 0.20^{b}$ & $14.71 \pm 0.13^{\mathrm{a}}$ & $11.32 \pm 0.22^{c}$ & $*$ & $13.24 \pm 0.23$ & $13.11 \pm 0.26$ & ns \\
\hline \multirow{7}{*}{ Chroma $C^{*}$} & 1 & $20.61 \pm 0.13^{a}$ & $15.68 \pm 0.10^{c}$ & $19.72 \pm 0.19^{b}$ & * & $18.33 \pm 0.29^{b}$ & $19.01 \pm 0.34^{\mathrm{a}}$ & * \\
\hline & 2 & $19.85 \pm 0.11^{\mathrm{a}}$ & $15.40 \pm 0.10^{c}$ & $18.69 \pm 0.12^{b}$ & $*$ & $17.83 \pm 0.27^{b}$ & $18.14 \pm 0.28^{\mathrm{a}}$ & $*$ \\
\hline & 3 & $19.29 \pm 0.10^{\mathrm{a}}$ & $15.40 \pm 0.11^{\mathrm{c}}$ & $17.50 \pm 0.16^{\mathrm{b}}$ & $*$ & $17.37 \pm 0.24$ & $17.42 \pm 0.24$ & ns \\
\hline & 4 & $18.72 \pm 0.12^{\mathrm{a}}$ & $15.15 \pm 0.12^{\mathrm{c}}$ & $15.92 \pm 0.18^{b}$ & * & $16.66 \pm 0.24$ & $16.53 \pm 0.24$ & ns \\
\hline & 5 & $18.23 \pm 0.14^{\mathrm{a}}$ & $15.06 \pm 0.14^{b}$ & $14.48 \pm 0.17^{c}$ & $*$ & $16.01 \pm 0.25$ & $15.83 \pm 0.26$ & ns \\
\hline & 6 & $17.42 \pm 0.19^{\mathrm{a}}$ & $14.86 \pm 0.13^{b}$ & $13.65 \pm 0.16^{c}$ & $*$ & $15.36 \pm 0.24$ & $15.26 \pm 0.27$ & ns \\
\hline & 7 & $16.06 \pm 0.26^{\mathrm{a}}$ & $14.83 \pm 0.12^{b}$ & $12.72 \pm 0.14^{c}$ & * & $14.63 \pm 0.24$ & $14.44 \pm 0.25$ & ns \\
\hline
\end{tabular}

$\mathrm{a}, \mathrm{b}, \mathrm{c}$ Means within a row followed by different superscript differ significantly at $p \leq 0.05$. MAP: modified atmosphere packaging; VP: vacuum packaging; OP: oxygen permeable. ${ }^{*} p \leq 0.05$; ns means non-significant.

Sekar et al. [39] researched buffalo meat and compared its color in aerobic, vacuum, and MAP packaging. In the study, the meat color was judged by a trained panel, and the scientists found that MAP gives a bright red color to the meat, followed by aerobic packaging and vacuum packaging, respectively. Moczkowska et al. [27] studied instrumental color in MAP and vacuum skin packaging (VSP) comparing with control and observed similar results of MAP meat being most reddish (higher $\mathrm{a}^{*}$ ) and VSP meat least reddish. Lagerstedt et al. [25] and Vitale et al. [23] agree that $\mathrm{Hi}_{2} \mathrm{O}_{2}$ MAP enhances meat color parameters. The bright red color in $\mathrm{Hi}_{2} \mathrm{O}_{2}$ MAP was due to higher oxygen concentration in $\mathrm{Hi}^{-\mathrm{O}_{2}} \mathrm{MAP}$, 
which allows the formation of a thick oxymyoglobin layer due to the deeper penetration of oxygen [40]. At the same time, the possible reason for an increase in lightness might be the oxidizing conditions in $\mathrm{Hi}_{2} \mathrm{O}_{2} \mathrm{MAP}$ that cause changes in the meat protein structure, leading to greater light dispersion hence higher $\mathrm{L}^{*}$ value [41]. Since air is removed in VP, more myoglobin is in deoxy form [42]. Therefore, the $\mathrm{a}^{*}$ value of VP meat was less than in $\mathrm{Hi}_{2} \mathrm{O}$ MAP and OP meat.

As shown in Table 2, aging significantly influenced the instrumental color. The $\mathrm{L}^{*}$ value of 7-day-aged buffalo meat was slightly higher for the first 5 days than fresh buffalo meat. Significant results were observed for the $L^{*}$ value on days 3 and 5 only. On days 6 and 7, aged buffalo meat indicated a lower $\mathrm{L}^{*}$ value. The 7 -day-aged buffalo meat had a higher $\mathrm{L}^{*}$ value on days 1 to 4 , with a lower $a^{*}$ on the subsequent 3 days.

Similarly, significant results were observed on day 1 . The $C^{*}$ value was also significantly higher in aged buffalo meat on days 1 and 2 . These findings agree with the observations of Vitale et al. [23], who showed that lightness, redness, and chroma values of longissimus thoracis et lumborum steaks aged 3 to 21 days under VP conditions were higher than unaged meat ( $48 \mathrm{~h}$ post mortem). While studying the influence of different aging times in VP on the instrumental color of young bulls' longissimus dorsi steaks, Lagerstedt et al. [25] also found increased lightness, redness, and yellowness in 5- and 15-day-aged meat as compared to unaged meat (72 h post mortem). The differences between the lightness, redness, and chroma values of pre-aged and aged meat can be justified by VP's blooming ability. As Ledward [43] described, the blooming of meat relies on several factors, including oxygen concentration, its diffusion into the meat, and muscle oxygen consumption rate. O'keeffe and Hood [44] and Bendall and Taylor [45] explained that the difference in color parameters of fresh and aged meat could reduce oxygen consumption rate over time in a vacuum pack. Therefore, oxygen penetrates deeper due to limited enzymatic activity, and a thick layer of oxymyoglobin is formed [46]. The color stability of fresh and aged buffalo meat in the present study did not differ. This was in agreement with the results of Vitale et al. [23] and Lagerstedt et al. [25]. However, Ledward [43] observed that aged meat turns brownish earlier as compared to fresh meat. Zakrys et al. [47] reported a negative correlation of $\mathrm{a}^{*}$ and positive correlation of $\mathrm{L}^{*}$ with days of the display, meaning that meat became less red and lighter with the passage of days in the retail display, and the present study partially agrees with this correlation as redness decreased during the 7 days of simulated retail display, while lightness increased up to 3 days only.

\subsection{Cooking Loss}

As shown in Table 3, the buffalo meat in MAP and VP showed a significantly higher cooking loss than OP buffalo meat at the end of 7 days of simulated retail display (Table 3). The higher cooking loss in MAP could be due to the higher protein oxidation leading to limited cytoskeletal protein degradation that enhanced cell shrinkage in the overall muscle structure [48].

Table 3. Effect of packaging and ageing on cooking loss (\%) and tenderness $\left(\mathrm{N} / \mathrm{cm}^{2}\right)$ of buffalo bulls longissimus lumborum steaks after 7 days of retail display.

\begin{tabular}{|c|c|c|c|c|c|c|c|}
\hline \multirow{2}{*}{ Parameters } & \multicolumn{3}{|c|}{ Packaging } & \multirow{2}{*}{$p$-Value } & \multicolumn{2}{|c|}{ Ageing } & \multirow{2}{*}{$p$-Value } \\
\hline & MAP & VP & OP & & 0 day & 7 day & \\
\hline Cooking loss & $31.62 \pm 0.34^{a}$ & $31.52 \pm 0.53^{a}$ & $29.12 \pm 0.40^{b}$ & * & $29.08 \pm 0.49^{b}$ & $30.42 \pm 0.49^{a}$ & * \\
\hline Tenderness & $44.87 \pm 1.03^{a}$ & $28.32 \pm 0.95^{\mathrm{c}}$ & $33.97 \pm 0.69^{b}$ & $* * *$ & $39.57 \pm 1.10^{\mathrm{a}}$ & $31.86 \pm 1.04^{b}$ & $* * *$ \\
\hline TBARS & $0.32 \pm 0.10^{a}$ & $0.20 \pm 0.08^{c}$ & $0.26 \pm 0.12^{b}$ & $* * *$ & $0.22 \pm 0.11^{b}$ & $0.25 \pm 0.11^{\mathrm{a}}$ & $* * *$ \\
\hline TVB-N & $10.54 \pm 0.25^{b}$ & $9.14 \pm 0.18^{c}$ & $14.30 \pm 0.28^{a}$ & $* * *$ & $8.26 \pm 0.34^{b}$ & $14.96 \pm 0.42^{a}$ & $* * *$ \\
\hline
\end{tabular}

$a, b, c$ Means within a row followed by different superscript differ significantly at $p \leq 0.05$. MAP: modified atmosphere packaging; VP: vacuum packaging; OP: oxygen permeable. ${ }^{*} p \leq 0.05 ;{ }^{* *} p \leq 0.001$. 
Cooking loss was higher in aged buffalo meat (Table 3). Wyrwisz et al. [49] also observed increased cooking loss after 7 days in vacuum packaging. This increased cooking loss might be due to the protein breakdown and loosening of muscle structure during aging [48,50-52].

\subsection{Warner-Bratzler Shear Force (WBSF)}

The effect of packaging type on WBSF values is presented in Table 3. WBSF values were significantly lowest for VP, followed by OP and MAP, respectively (Table 3). Lagerstedt et al. [25,35] and Vitale et al. [23] also found similar results. Zakrys et al. [47] found that when oxygen concentration is increased from $10 \%$ to $80 \%$, the increase in concentration tends to increase shear force values during storage of 15 days. The lowest WBSF values in VP were reported because the tenderizing process by proteolytic enzymes continues in VP [23]. This is also supported by the study conducted by Sekar et al. [39], who found that buffalo meat stored in VP had a significantly longer sarcomere length and smaller myofibrillar fragmentation index than meat stored in $\mathrm{Hi}_{-} \mathrm{O}_{2} \mathrm{MAP}$ and OP. At the same time, these two proposed theories that could explain the increase in WBSF values in $\mathrm{Hi}-\mathrm{O}_{2}$ MAP. The first is the inactivation of enzymes involved in oxidation conditioning, leading to a slower tenderization process [53]. Second, protein cross-linkages are formed in a high oxygen environment, resulting in tougher meat $[5,54,55]$. Usually, VP is not preferred by consumers due to the purple color of the meat. However, Scandinavian customers preferred steaks from oxygen-free packaging in terms of willingness to pay more, sensory quality, and overall liking [56], which indicates better quality is preserved in VP.

As shown in Table 3, aging significantly reduced the WBSF (improved tenderness) of the buffalo meat compared to unaged buffalo meat (Table 3). Vitale et al. [23] studied the effect of $0,3,6,8,14$, and 21 days aging on tenderness and found that aged meat was tenderer than unaged meat. Similarly, Moczkowska et al. [27] observed lower WBSF values in 14 and 28 days vacuum skin-pack aged meat compared to the unaged meat. Many authors have observed a similar tenderizing effect of aging in cattle beef [35,57-60]. The decrease in WBSF values could be due to the breakdown of myofibrillar cytoskeletal proteins by proteolytic enzymes, i.e., calpains, cathepsins, and caspases [48,50-52]. In this study, WBSF values of young buffalo meat were under the acceptable threshold of $40.2 \mathrm{~N}$ for consumers, as indicated by Huffman et al. [61].

\subsection{Lipid Oxidation}

Packaging type significantly affected TBAR values (Table 3). The highest TBAR values were observed in MAP, whereas the lowest TBAR values were noticed in VP at the end of the 7 days of simulated retail display. The present study results are in accordance with the findings of Clausen et al. [62]. The authors reported that packaging type significantly impacts the TBAR values, the lowest TBAR values in anaerobic packaging and the highest in aerobic packaging. Similarly, Amaral et al. [63] presented that oxygen exposure is a critical factor for lipid oxidation in meat products; higher oxygen exposure leads to enhanced lipid oxidation, following the present study's results. In other studies, authors found similar results, lower TBAR values in vacuum-packed meat and highest lipid oxidation values in modified atmosphere packaging with high oxygen concentration [64,65].

As shown in Table 3, aging also significantly affected TBAR values. The highest TBAR values were observed in 7 days aged meat. Ismail et al. [66] found similar findings in a study on beef rounds. The authors showed that lipid oxidation increased with the increasing aging time. Likewise, Karami et al. [67] also found that TBAR values were increased with increasing aging time. In contrast, Rant et al. [68] and Marrone et al. [69] found a non-significant impact of aging time on the oxidative stability of meat.

\subsection{Total Volatile Basic Nitrogen (TVB-N)}

Packaging type significantly affected TVB-N values; the highest TVB-N values $(14.30 \mathrm{mg} /$ $100 \mathrm{~g}$ ) were observed in OP, followed by VP and MAP. However, the highest values were 
under the acceptable threshold level of TVB-N, which is less than $20 \mathrm{mg} / 100 \mathrm{~g}$ [70]. The TVB-N compounds are toxic nitrogenous compounds resulting from microbial contamination, and enzymatic actions can ultimately lead to sensory changes; they are an excellent indicator of meat safety and freshness [71]. Mansur et al. [72] exhibited similar results that aerobic storage showed the highest level of TVB-N during 9-day storage than the vacuum packaging. Likewise, Lyu et al. [73] found that MAP meat had lower TVB-N than vacuum packaged meat.

Aging significantly affected the TVB-N values; the highest values were noticed in 7-day-aged meat. Similarly, Chen et al. [37] showed that TVB-N level increased with increasing storage duration of meat. In a study, the authors found that the TVB-N level increased during a 46-day-storage period of beef loins [73]. In a recent study, Azarifar et al. [74] reported that the TVB-N level was increased with storage time that exceeded the unacceptable limit after 12 days at $4{ }^{\circ} \mathrm{C}$.

\section{Conclusions}

In conclusion, $\mathrm{Hi}-\mathrm{O}_{2}$ MAP improved the buffalo meat's color and shelf life compared to the OP; however, it negatively affected the WBSF and TBARS values. While VP decreased the WBSF values and improved the color shelf life, compared to $\mathrm{Hi}_{2} \mathrm{O}_{2} \mathrm{MAP}$, it has a drawback of giving purple-colored meat. The aging of meat in different simulated retail displays for 7 days improved the meat color and tenderness. Therefore, different packaging types and aging times for buffalo meat should be chosen according to the customers' requirements to ensure high-quality meat and meat products.

Author Contributions: Conceptualization, M.H.J., M.K.Y., M.I., A.M., J.N. and I.H.B.; methodology, M.U.G., M.J.A., K.N., A.R., F.H. and A.A.; software, A.M., I.H.B. and M.U.G.; validation, M.H.J., I.H.B., J.N., A.R. and A.A.; formal analysis, K.N., M.K.Y., M.I. and F.H.; investigation, I.H.B., M.H.J., M.U.G. and M.K.Y.; resources, M.H.J.; data curation, I.H.B., M.U.G., F.H., M.K.Y. and A.R.; writingoriginal draft preparation, M.H.J., M.I., A.M., I.H.B., M.J.A. and A.A.; writing-review and editing, M.H.J., A.A., J.N., F.H., K.N., A.R. and I.H.B.; visualization, M.K.Y., M.I. and A.M.; supervision, M.H.J., M.J.A. and I.H.B.; project administration, M.H.J., I.H.B. and M.U.G.; funding acquisition, M.H.J. All authors have read and agreed to the published version of the manuscript.

Funding: The authors are thankful to the Higher Education Commission of Pakistan for funding the cost of meat samples and the packaging material of this research project under the Problem Based Inter-disciplinary Programme (PBIDP/R\&D/HEC/1226). Project titled “Using Innovative Processing and Packaging Technologies to improve meat quality, eating quality, and shelf life of fresh beef and beef products".

Institutional Review Board Statement: The study was conducted according to the guidelines of the Declaration of Helsinki, and approved by the Institutional Ethical Review Committee, Office of Research Innovation and Commercialization (ORIC), the University of Veterinary and Animal Sciences (UVAS), Lahore, Pakistan (vide letter no. DR/325, 11 July 2021).

Informed Consent Statement: Not applicable.

Data Availability Statement: The data are not publicly available.

Acknowledgments: The authors are very thankful to the Department of Meat Science and Technology staff, University of Veterinary and Animal Sciences, Pakistan, for the excellent support in executing this research trial.

Conflicts of Interest: The authors declare no conflict of interest.

\section{References}

1. Gómez, M.; Lorenzo, J.M. Effect of packaging conditions on shelf-life of fresh foal meat. Meat Sci. 2012, 91, 513-520. [CrossRef] [PubMed]

2. Singh, R.K.; Singh, N. Quality of packaged foods. In Innovations in Food Packaging; Jung, H.H., Ed.; Academic Press: Cambridge, MA, USA, 2005; pp. 24-44.

3. Ijaz, M.; Li, X.; Zhang, D.; Hussain, Z.; Ren, C.; Bai, Y.; Zheng, X. Association between meat color of DFD beef and other quality attributes. Meat Sci. 2020, 161, 107954. [CrossRef] [PubMed] 
4. Jaspal, M.H.; Badar, I.H.; Amjad, O.B.; Yar, M.K.; Ijaz, M.; Manzoor, A.; Nasir, J.; Asghar, B.; Ali, S.; Nauman, K.; et al. Effect of Wet Aging on Color Stability, Tenderness, and Sensory Attributes of Longissimus lumborum and Gluteus medius Muscles from Water Buffalo Bulls. Animals 2021, 11, 2248. [CrossRef] [PubMed]

5. Kim, Y.H.; Huff-Lonergan, E.; Sebranek, J.G.; Lonergan, S.M. High-oxygen modified atmosphere packaging system induces lipid and myoglobin oxidation and protein polymerization. Meat Sci. 2010, 85, 759-767. [CrossRef] [PubMed]

6. Carpenter, C.E.; Cornforth, D.P.; Whittier, D. Consumer preferences for beef color and packaging did not affect eating satisfaction. Meat Sci. 2001, 57, 359-363. [CrossRef]

7. Mcmillin, K.W. Where is map going? A review and future potential of modified atmosphere packaging for meat. Meat Sci. 2008, 80, 43-65. [CrossRef] [PubMed]

8. Geesink, G.; Robertson, J.; Ball, A. The effect of retail packaging method on objective and consumer assessment of beef quality traits. Meat Sci. 2015, 104, 85-89. [CrossRef] [PubMed]

9. Jongberg, S.; Wen, J.; Tørngren, M.A.; Lund, M.N. Effect of high-oxygen atmosphere packaging on oxidative stability and sensory quality of two chicken muscles during chill storage. Food Packag. Shelf Life 2014, 1, 38-48. [CrossRef]

10. Jayasingh, P.; Cornforth, D.P.; Carpenter, C.E.; Whittier, D. Evaluation of carbon monoxide treatment in modified atmosphere packaging or vacuum packaging to increase color stability of fresh beef. Meat Sci. 2001, 59, 317-324. [CrossRef]

11. Filgueras, R.S.; Gatellier, P.; Aubry, L.; Thomas, A.; Bauchart, D.; Durand, D.; Zambiazi, R.C.; Sante-Lhoutellier, V. Colour, lipid and protein stability of Rhea americana meat during air-and vacuum-packaged storage: Influence of muscle on oxidative processes. Meat Sci. 2010, 86, 665-673. [CrossRef]

12. Lindahl, G. Colour stability of steaks from large beef cuts aged under vacuum or high oxygen modified atmosphere. Meat Sci. 2011, 87, 428-435. [CrossRef]

13. Ijaz, M.; Yar, M.K.; Badar, I.H.; Ali, S.; Islam, M.; Jaspal, M.H.; Guevara-Ruiz, D. Meat production and supply chain under COVID-19 scenario: Current trends and future prospects. Front. Vet. Sci. 2021, 8, 660736. [CrossRef]

14. Pietrasik, Z.; Dhanda, J.S.; Shand, P.J.; Pegg, R.B. Influence of injection, packaging, and storage conditions on the quality of beef and bison steaks. J. Food Sci. 2006, 71, S110-S118. [CrossRef]

15. Resurreccion, A.V.A. Sensory aspects of consumer choices for meat and meat products. Meat Sci. 2004, 66, 11-20. [CrossRef]

16. Ijaz, M.; Li, X.; Zhang, D.; Bai, Y.; Hou, C.; Hussain, Z.; Huang, C. Sarcoplasmic and myofibrillar phosphoproteins profile in beef M. longissimus thoracis with different $\mathrm{pH}_{\mathrm{u}}$ at different days postmortem. J. Sci. Food Agric. 2021. [CrossRef]

17. Jaspal, M.H.; Ijaz, M.; ul Haq, H.A.; Yar, M.K.; Asghar, B.; Manzoor, A.; Badar, I.H.; Ullah, S.; Islam, M.S.; Hussain, J. Effect of oregano essential oil or lactic acid treatments combined with air and modified atmosphere packaging on the quality and storage properties of chicken breast meat. LWT 2021, 146, 111459. [CrossRef]

18. Li, X.; Zhang, D.; Ijaz, M.; Tian, G.; Chen, J.; Du, M. Colour characteristics of beef longissimus thoracis during early $72 \mathrm{~h}$ postmortem. Meat Sci. 2020, 170, 108245. [CrossRef] [PubMed]

19. Ijaz, M.; Jaspal, M.H.; Hayat, Z.; Yar, M.K.; Badar, I.H.; Ullah, S.; Hussain, Z.; Ali, S.; Farid, M.U.; Farooq, M.Z.; et al. Effect of animal age, postmortem chilling rate, and aging time on meat quality attributes of water buffalo and humped cattle bulls. Anim. Sci. J. 2020, 91, 13354. [CrossRef]

20. Smaldone, G.; Marrone, R.; Vollano, L.; Peruzy, M.F.; Barone, C.M.A.; Ambrosio, R.L.; Anastasio, A. Microbiological, rheological and physical-chemical characteristics of bovine meat subjected to a prolonged ageing period. Ital. J. Food Saf. 2019, 8, 131-136. [CrossRef]

21. Clerjon, S.; Peyrin, F.; Lepetit, J. Frontal UV-visible fluorescence polarization measurement for bovine meat ageing assessment. Meat Sci. 2011, 88, 28-35. [CrossRef] [PubMed]

22. McKenna, D.R.; Mies, P.D.; Baird, B.E.; Pfeiffer, K.D.; Ellebracht, J.W.; Savell, J.W. Biochemical and physical factors affecting discoloration characteristics of 19 bovine muscles. Meat Sci. 2005, 70, 665-682. [CrossRef]

23. Vitale, M.; Pérez-Juan, M.; Lloret, E.; Arnau, J.; Realini, C.E. Effect of aging time in vacuum on tenderness, and color and lipid stability of beef from mature cows during display in high oxygen atmosphere package. Meat Sci. 2014, 96, $270-277$. [CrossRef] [PubMed]

24. Hur, S.J.; Jin, S.K.; Park, J.H.; Jung, S.W.; Lyu, H.J. Effect of modified atmosphere packaging and vacuum packaging on quality characteristics of low grade beef during cold storage. Asian Australas. J. Anim. 2013, 26, 1781-1789. [CrossRef] [PubMed]

25. Lagerstedt, Å.; Lundström, K.; Lindahl, G. Influence of vacuum or high-oxygen modified atmosphere packaging on quality of beef M. longissimus dorsi steaks after different ageing times. Meat Sci. 2011, 87, 101-106. [CrossRef]

26. Lindahl, G.; Lagerstedt, Å.; Ertbjerg, P.; Sampels, S.; Lundström, K. Ageing of large cuts of beef loin in vacuum or high oxygen modified atmosphere-Effect on shear force, calpain activity, desmin degradation and protein oxidation. Meat Sci. 2010, 85, 160-166. [CrossRef]

27. Moczkowska, M.; Półtorak, A.; Montowska, M.; Pospiech, E.; Wierzbicka, A. The effect of the packaging system and storage time on myofibrillar protein degradation and oxidation process in relation to beef tenderness. Meat Sci. 2017, 130, 7-15. [CrossRef]

28. Zakrys-Waliwander, P.I.; O'sullivan, M.G.; O'neill, E.E.; Kerry, J.P. The effects of high oxygen modified atmosphere packaging on protein oxidation of bovine M. longissimus dorsi muscle during chilled storage. Food Chem. 2012, 131, 527-532. [CrossRef]

29. Jaspal, M.H.; Ijaz, M.; Akhtar, M.J.; Nasir, J.; Ullah, S.; Badar, I.H.; Yar, M.K.; Ahmad, A. Effect of Carcass Electrical Stimulation and Suspension Methods on Meat Quality Characteristics of Longissimus lumborum of Young Buffalo (Bubalus bubalis) Bulls. Food Sci. Anim. Resour. 2021, 41, 34-44. [CrossRef] [PubMed] 
30. Cappelli, G.; Di Vuolo, G.; Gerini, O.; Noschese, R.; Bufano, F.; Capacchione, R.; Rosini, S.; Limone, A.; De Carlo, E. Italian Tracing System for Water Buffalo Milk and Processed Milk Products. Animals 2021, 11, 1737. [CrossRef]

31. Ünal, E.Ö.; Issık, R.; Sen, A.; Geyik Kus s, E.; Soysal, M.I. Evaluation of Genetic Diversity and Structure of Turkish Water Buffalo Population by Using 20 Microsatellite Markers. Animals 2021, 11, 1067. [CrossRef]

32. Luz, P.A.C.D.; Jorge, A.M.; Francisco, C.D.L.; Mello, J.L.M.D.; Santos, C.T.; Andrighetto, C. Chemical-physical characteristics of buffalo (Bubalus bubalis) meat subjected to different aging times. Acta Sci. 2017, 39, 419-428. [CrossRef]

33. Badar, I.H.; Jaspal, M.H.; Yar, M.K.; Ijaz, M.; Khalique, A.; Zhang, L.; Manzoor, A.; Ali, S.; Rahman, A.; Husnain, F. Effect of strain and slaughter age on production performance, meat quality and processing characteristics of broilers reared under tropical climatic conditions. Eur. Poult. Sci. 2021, 85. [CrossRef]

34. Moczkowska, M.; Półtorak, A.; Wierzbicka, A. The effect of ageing on changes in myofibrillar protein in selected muscles in relation to the tenderness of meat obtained from cross-breed heifers. Int. J. Food Sci. Technol. 2017, 52, 1375-1382. [CrossRef]

35. Lagerstedt, Å.; Ahnström, M.L.; Lundström, K. Vacuum skin pack of beef-A consumer friendly alternative. Meat Sci. 2011, 88, 391-396. [CrossRef]

36. Zhang, Y.; Qin, L.; Mao, Y.; Hopkins, D.L.; Han, G.; Zhu, L.; Luo, X. Carbon monoxide packaging shows the same color improvement for dark cutting beef as high oxygen packaging. Meat Sci. 2018, 137, 153-159. [CrossRef] [PubMed]

37. Chen, X.; Zhang, Y.; Yang, X.; Hopkins, D.L.; Zhu, L.; Dong, P.; Liang, R.; Luo, X. Shelf-life and microbial community dynamics of super-chilled beef imported from Australia to China. Food Res. Int. 2019, 120, 784-792. [CrossRef]

38. Duncan, D.B. Multiple range and multiple F tests. Biometrics 1955, 11, 1-42. [CrossRef]

39. Sekar, A.; Dushyanthan, K.; Radhakrishnan, K.T.; Babu, R.N. Effect of modified atmosphere packaging on structural and physical changes in buffalo meat. Meat Sci. 2006, 72, 211-215. [CrossRef] [PubMed]

40. Jeremiah, L. Packaging alternative to deliver fresh meats using short-or long-term distribution. Food Res. Int. 2001, 34, 749-772. [CrossRef]

41. MacDougall, D.B. Changes in the colour and opacity of meat. Food Chem. 1982, 9, 75-88. [CrossRef]

42. Li, X.; Lindahl, G.; Zamaratskaia, G.; Lundström, K. Influence of vacuum skin packaging on color stability of beef longissimus lumborum compared with vacuum and high-oxygen modified atmosphere packaging. Meat Sci. 2012, 92, 604-609. [CrossRef]

43. Ledward, D. Color of raw and cooked meat. In The Chemistry of Muscle-Based Foods; Ledward, D.A., Johnston, D.E., Knight, M.K., Eds.; The Royal Society of Chemistry: Cambridge, UK, 1992; pp. 128-144.

44. O'keeffe, M.; Hood, D.E. Anoxic storage of fresh beef. 1: Nitrogen and carbon dioxide storage atmospheres. Meat Sci. 1980, 5, 27-39. [CrossRef]

45. Bendall, J.R.; Taylor, A.A. Consumption of oxygen by the muscles of beef animals and related species. II. Consumption of oxygen by post-rigor muscle. J. Sci. Food Agric. 1972, 23, 707-719. [CrossRef]

46. Lindahl, G.; Karlsson, A.H.; Lundström, K.; Andersen, H.J. Significance of storage time on degree of blooming and colour stability of pork loin from different crossbreeds. Meat Sci. 2006, 72, 603-612. [CrossRef]

47. Zakrys, P.I.; Hogan, S.A.; O'sullivan, M.G.; Allen, P.; Kerry, J.P. Effects of oxygen concentration on the sensory evaluation and quality indicators of beef muscle packed under modified atmosphere. Meat Sci. 2008, 79, 648-655. [CrossRef]

48. Huff-Lonergan, E.; Lonergan, S.M. Mechanisms of water-holding capacity of meat: The role of postmortem biochemical and structural changes. Meat Sci. 2005, 71, 194-204. [CrossRef]

49. Wyrwisz, J.; Moczkowska, M.; Kurek, M.; Stelmasiak, A.; Półtorak, A.; Wierzbicka, A. Influence of 21 days of vacuum-aging on color, bloom development, and WBSF of beef semimembranosus. Meat Sci. 2016, 122, 48-54. [CrossRef]

50. Hopkins, D.; Taylor, R. Post-mortem muscle proteolysis and meat tenderness. In Muscle Development of Livestock Animals: Physiology, Genetics, and Meat Quality; Everts, M., Pas, T.M., Haagsman, H., Eds.; CABI Publishing: Oxfordshire, UK, 2004; pp. 363-388.

51. Li, X.; Zhang, D.; Ren, C.; Bai, Y.; Ijaz, M.; Hou, C.; Chen, L. Effects of protein posttranslational modifications on meat quality: A review. Compr. Rev. Food Sci. Food Saf. 2021, 20, 289-331. [CrossRef]

52. Koohmaraie, M.; Geesink, G.H. Contribution of postmortem muscle biochemistry to the delivery of consistent meat quality with particular focus on the calpain system. Meat Sci. 2006, 74, 34-43. [CrossRef]

53. Rowe, L.J.; Maddock, K.R.; Lonergan, S.M.; Huff-Lonergan, E. Oxidative environments decrease tenderization of beef steaks through inactivation of $\mu$-calpain. J. Anim. Sci. 2004, 82, 3254-3266. [CrossRef]

54. Lund, M.N.; Christensen, M.; Fregil, L.; Hviid, M.S.; Skibsted, L.H. Effect of high-oxygen atmosphere packaging on mechanical properties of single muscle fibres from bovine and porcine longissimus dorsi. Eur. Food Res. Technol. 2008, 227, 1323-1328. [CrossRef]

55. Lund, M.N.; Lametsch, R.; Hviid, M.S.; Jensen, O.N.; Skibsted, L.H. High-oxygen packaging atmosphere influences protein oxidation and tenderness of porcine longissimus dorsi during chill storage. Meat Sci. 2007, 77, 295-303. [CrossRef]

56. Aaslyng, M.D.; Tørngren, M.A.; Madsen, N.T. Scandinavian consumer preference for beef steaks packed with or without oxygen. Meat Sci. 2010, 85, 519-524. [CrossRef]

57. Campo, M.M.; Santolaria, P.; Sañudo, C.; Lepetit, J.; Olleta, J.L.; Panea, B.; Albertí, P. Assessment of breed type and ageing time effects on beef meat quality using two different texture devices. Meat Sci. 2000, 55, 371-378. [CrossRef] 
58. Mach, N.; Bach, A.; Realini, C.E.; Furnols, M.F.I.; Velarde, A.; Devant, M. Burdizzo pre-pubertal castration effects on performance, behaviour, carcass characteristics, and meat quality of Holstein bulls fed high-concentrate diets. Meat Sci. 2009, 81, 329-334. [CrossRef]

59. Marti, S.; Realini, C.E.; Bach, A.; Pérez-Juan, M.; Devant, M. Effect of castration and slaughter age on performance, carcass, and meat quality traits of Holstein calves fed a high-concentrate diet. J. Anim. Sci. 2013, 91, 1129-1140. [CrossRef]

60. Sañudo, C.; Macie, E.S.; Olleta, J.L.; Villarroel, M.; Panea, B.; Albert1, P. The effects of slaughter weight, breed type and ageing time on beef meat quality using two different texture devices. Meat Sci. 2004, 66, 925-932. [CrossRef] [PubMed]

61. Huffman, K.L.; Miller, M.F.; Hoover, L.C.; Wu, C.K.; Brittin, H.C.; Ramsey, C.B. Effect of beef tenderness on consumer satisfaction with steaks consumed in the home and restaurant. J. Anim. Sci. 1996, 74, 91-97. [CrossRef]

62. Clausen, I.; Jakobsen, M.; Ertbjerg, P.; Madsen, N.T. Modified atmosphere packaging affects lipid oxidation, myofibrillar fragmentation index and eating quality of beef. Packag. Technol. Sci. 2009, 22, 85-96. [CrossRef]

63. Amaral, A.B.; Silva, M.V.D.; Lannes, S.C.D.S. Lipid oxidation in meat: Mechanisms and protective factors-A review. Food Sci. Technol. 2018, 38, 1-15. [CrossRef]

64. Hussain, Z.; Li, X.; Zhang, D.; Hou, C.; Ijaz, M.; Bai, Y.; Zheng, X. Influence of adding cinnamon bark oil on meat quality of ground lamb during storage at $4{ }^{\circ} \mathrm{C}$. Meat Sci. 2021, 171, 108269. [CrossRef]

65. Cayuela, J.M.; Gil, M.D.; Bañón, S.; Garrido, M.D. Effect of vacuum and modified atmosphere packaging on the quality of pork loin. Eur. Food Res. Technol. 2004, 219, 316-320. [CrossRef]

66. Ismail, H.A.; Lee, E.J.; Ko, K.Y.; Ahn, D.U. Effects of aging time and natural antioxidants on the color, lipid oxidation and volatiles of irradiated ground beef. Meat Sci. 2008, 80, 582-591. [CrossRef] [PubMed]

67. Karami, M.; Alimon, A.R.; Sazili, A.Q.; Goh, Y.M.; Ivan, M. Effects of dietary antioxidants on the quality, fatty acid profile, and lipid oxidation of longissimus muscle in Kacang goat with aging time. Meat Sci. 2011, 88, 102-108. [CrossRef] [PubMed]

68. Rant, W.; Radzik-Rant, A.; Świątek, M.; Niżnikowski, R.; Szymańska, Ż.; Bednarczyk, M.; Orłowski, E.; Morales-Villavicencio, A.; Ślęzak, M. The effect of aging and muscle type on the quality characteristics and lipid oxidation of lamb meat. Arch. Anim. Breed. 2019, 62, 383-391. [CrossRef] [PubMed]

69. Marrone, R.; Salzano, A.; Di Francia, A.; Vollano, L.; Di Matteo, R.; Balestrieri, A.; Anastasio, A.; Barone, C.M.A. Effects of feeding and maturation system on qualitative characteristics of buffalo meat (Bubalus bubalis). Animals 2020, 10, 899. [CrossRef] [PubMed]

70. Bekhit, A.E.D.A.; Holman, B.W.; Giteru, S.G.; Hopkins, D.L. Total volatile basic nitrogen (TVB-N) and its role in meat spoilage: A review. Trends Food Sci. Technol. 2021, 109, 280-302. [CrossRef]

71. Qiao, L.; Tang, X.; Dong, J. A feasibility quantification study of total volatile basic nitrogen (TVB-N) content in duck meat for freshness evaluation. Food Chem. 2017, 237, 1179-1185. [CrossRef]

72. Mansur, A.R.; Song, E.J.; Cho, Y.S.; Nam, Y.D.; Choi, Y.S.; Kim, D.O.; Seo, D.H.; Nam, T.G. Comparative evaluation of spoilagerelated bacterial diversity and metabolite profiles in chilled beef stored under air and vacuum packaging. Food Microbiol. 2019, 77, 166-172. [CrossRef]

73. Lyu, F.; Shen, K.; Ding, Y.; Ma, X. Effect of pretreatment with carbon monoxide and ozone on the quality of vacuum packaged beef meats. Meat Sci. 2016, 117, 137-146. [CrossRef]

74. Azarifar, M.; Ghanbarzadeh, B.; Abdulkhani, A. The effects of gelatin-CMC films incorporated with chitin nanofiber and Trachyspermum ammi essential oil on the shelf life characteristics of refrigerated raw beef. Int. J. Food Microbiol. 2020, 318, 108493. [CrossRef] [PubMed] 